\title{
Study on Nutrient Balances of Newly Developed Lowland Rice Fields at Kleseleon Village, Malaka District, Nusa Tenggara Timur
}

\author{
Sukristiyonubowo ${ }^{1)}$ and Damasus Riyanto ${ }^{2)}$ \\ ${ }^{1 *}$ Soil Research Institute, Indonesian Agency for Agricultural Research and Development, \\ Jln Tentara Pelajar 12 Bogor, Indonesia \\ ${ }^{2}$ Jogyakarta Assessment Institute for Agricultural Technology, IndonesianAgency for Agricultural Research and \\ Development, Jalan Stadion Maguwohardjo 22 Karang Sari, Sleman, D.I.Jogyakarta, Indonesia, \\ *email:sukristiyonuboworicky@yahoo.com
}

Received August 22, 2019; Revised July 20, 2020; Accepted 23 September 2020

\begin{abstract}
The land allocated for newly opened lowland rice can be from ultisols, oxisols, inceptisols, and potential acid sulfate soils. The study was aimed to evaluate nitrogen $(\mathrm{N})$, phosphorous $(\mathrm{P})$, and potassium $(\mathrm{K})$ inputs - outputs of newly developed lowland rice under different treatments and to validate the N, P, and K recommended applications rate according to N, P, and K balances. The study was conducted in Kleseleon village, Malaka District. Five treatments were tested namely T0: farmers practices, T1: NPK at recommendation rate + Rice straw compost, T2: NPK at recommendation rate + Smart + Rice straw compost, T3: $3 / 4 \mathrm{NPK}$ at recommendation rate + Smart + Rice straw compost, and T4: NPK at recommendation rate + Smart + Rice straw compost. The treatments were arranged in a randomized complete block design with three replications. The nutrient balances were constructed according to the difference between nutrient inputs and losses. The results indicated that there were surplus $\mathrm{N}, \mathrm{P}$, and $\mathrm{K}$ across the treatments and more than adequate to replace N, P, and $\mathrm{K}$ removed by harvest products. The suggested N, P, and K application rates were $100 \mathrm{~kg}$ urea, $100 \mathrm{~kg} \mathrm{SP}-36$, and $100 \mathrm{~kg} \mathrm{KCl}$ with the addition of compost $3 \mathrm{Mg} \mathrm{ha}^{-1}$ season $^{-1}$.
\end{abstract}

Keywords: Newly developed lowland rice, nutrient balances, nutrient input, nutrient losses, nutrient surplus

\begin{abstract}
ABSTRAK
Tanah dialokasikan untuk padi sawah yang baru dibuka dapat berasal dari ultisols, oxisols, inceptisols dan potensi tanah asam sulfat. Penelitian dilakukan di Desa Kleseleon, Kabupaten Malaka pada tahun 2014. Lima perlakuan yang diujikan yaitu T0: Praktik petani, T1: NPK tingkat rekomendasi + Kompos jerami, T2: NPK tingkat rekomendasi + smart + Kompos jerami, T3: 3/4 NPK pada tingkat rekomendasi + Smart + Kompos jerami padi dan T4: NPK pada tingkat rekomendasi + Smart + Kompos jerami padi, dimana aplikasi N, P dan K dibagi dua kali. Perlakuan disusun dalam Rancangan Acak Kelompok Lengkap dengan tiga ulangan. Keseimbangan hara dibangun menurut perbedaan antara hara yang masukan dan diambil tanaman padi. Tujuannya adalah (1) untuk mengevaluasi masukan - keluaran nitrogen, fosfor dan kalium dan (2) untuk memvalidasi tingkat rekomendasi nitrogen, fosfor dan kalium menurut keseimbangan nitrogen, fosfor dan kalium. Hasil menunjukkan bahwa ada kelebihan N, P dan K di seluruh perlakuan dan lebih dari cukup untuk menggantikan N, P dan K yang dihilangkan oleh produk panen. Dosis aplikasi N, P dan $\mathrm{K}$ adalah $100 \mathrm{~kg}$ urea, $100 \mathrm{~kg} \mathrm{SP}-36$ dan $100 \mathrm{~kg} \mathrm{KCl}$ dengan penambahan kompos $3 \mathrm{Mg} \mathrm{ha}^{-1}$ musim $^{-1}$.
\end{abstract}

Kata Kunci: keseimbangan hara, unsur hara yang diterima, unsur hara yang diambil tanaman, sawah bukaan baru, kelebihan unsur hara

\section{INTRODUCTION}

The land granted for newly opened low land rice fields in Nusa Tenggara Timur Province have

J Trop Soils, Vol. 25, No. 3, 2020: 137-145

ISSN 0852-257X; E-ISSN 2086-6682 many shortcomings (Sukristiyonubowo et al. 2014), namely the soils are basic with a low level of macroand micro-nutrients. Furthermore, a study on the nutrient balances of newly developed lowland rice in Indonesia neither simple nor complete nutrient balance is still rare and not well documented (Sukristiyonubowo et al. 2016). A complete nutrient 
balance is very complicated, therefore, the researchers reported that most assessments are partial analysis of these in-and output data (Miller et al. 1976. Smaling et al. 1993; Drechsel et al. 2001; Wijnhoud et al.2003). Also, the quantification of nutrient inputs and outputs is important for agronomical, economic, and environmental analyses.

According to the researchers, the differences between nutrient gains and losses are called nutrients balance. Nutrient coming from fertilizers (IN1), returned crop residues (IN-2), irrigation (IN-3), rainfall (IN4), as well as biological nitrogen fixation is grouped as nutrient inputs (Sukristiyonubowo et al. 2010; Sukristiyonubowo 2007; Wijnhoud et al. 2003; Lefroy and Konboon 1999; Smaling et al. 1993). Nutrient losses include removal through harvested biomass (all nutrients), erosion (all nutrients), leaching (mainly nitrate, potassium, calcium, and magnesium), fixation (mainly phosphate), and volatilization (mainly nitrogen and sulfur). Researchers concluded when the nutrient removals are not replaced by sufficient application of fertilizers or returning of biomass, soil mining takes place and crop production does not reach its potential yields and finally reduces (Sukristiyonubowo et al. 2012; Sukristiyonubowo et al. 2010; Sukristiyonubowo 2007; Uexkul 1989).

According to many researchers, nutrient balances in dry land and wetland crops can be developed at different scales and purposes, including (a) plot, (b) field, farm or catchment, (c) district, province, and (d) country scale (Sukristiyonubowo et al. 2012; Sukristiyonubowo et al. 2010; Sukristiyonubowo 2007; Bationo et al. 1998; Hashim et al. 1998; Van den Bosch et al. 1998a; Van den Bosch et al. 1998b; Syers et al. 1996; Smaling et al. 1993; and Stoorvogel et al. 1993). Many studies indicated that at plot, farm, district, province, and national levels, agricultural production is characterized by a negative nutrient balance (Sukristiyonubowo 2017; Sukristiyonubowo et al. 2012; Sukristiyonubowo 2007; Nkonya 2005; Sheldrick 2003; Harris 1998; Van den Bosch et al. 1998a; Van den Bosch et al. 1998b). In upland crop, a long-term nitrogen experiment at plot scale in the dry land sloping area of Kuamang Kuning, Jambi Province, Indonesia confirmed that the balance in the plot without input is deficit $4 \mathrm{~kg} \mathrm{~N} \mathrm{ha}^{-1} \mathrm{yr}^{-1}$. However, this did not happen in the plots treated with a combination of high fertilizer application rate and Flemingia congesta leaves planted in a hedgerow system (Santoso et al. 1995).

The objectives of the study were (a) to evaluate nitrogen, phosphorous, and potassium inputs - outputs of newly developed lowland rice under different promising treatments and (b) to validate the $\mathrm{N}, \mathrm{P}$ and $\mathrm{K}$ recommended applications rate. It was hypothesized that proper $\mathrm{N}, \mathrm{P}$, and $\mathrm{K}$ fertilizer applications rate based on $\mathrm{N}, \mathrm{P}$, and $\mathrm{K}$ studies lead to optimal rice yield.

\section{MATERIALS AND METHODS}

\section{Study Sites}

A study on nitrogen, phosphorous, and potassium balances of newly developed lowland rice was conducted in Kleseleon Village, Malaka District, Nusa Tenggara Timur Province, in 2014. Soil type was ustifluvent with ustic to hemic soil moisture regimes. The site was relatively flat and developed in 2011.

\section{Research Design}

Five promising treatments were tested namely T0: farmers practices (as control), T1: NPK with recommendation rate + Rice Straw Compost, T2: NPK with recommendation rate + Smart + Rice Straw Compost, T3: $3 / 4$ NPK with recommendation rate + Smart + Rice Straw Compost, and T4: NPK with recommendation rate + Smart + Rice Straw Compost. These treatments were constructed according to the fact that a soil fertility status was classified as low with soil $\mathrm{pH}$ about 8.02 to 8.20 , low soil organic carbon, and the farmers did not apply $\mathrm{N}, \mathrm{P}$, and $\mathrm{K}$ fertilizers properly and some did not apply $\mathrm{K}$ fertilizer and organic fertilizer.

The treatments were arranged in a randomized complete block design (RCBD) and replicated three times. The plot sizes were $5 \mathrm{~m} \times 5 \mathrm{~m}$ with the distance among the plot was $50 \mathrm{~cm}$ and between replication was about $100 \mathrm{~cm}$.

\section{Fertilizer and Compost Application}

NPK fertilizers used were originated from single fertilizers namely urea, SP-36 (Super Phosphate), and $\mathrm{KCl}$ (potassium chloride). Based on the direct measurement with Soil Test Kits, the recommendation rate was determined by about 250 $\mathrm{kg}$ urea, $100 \mathrm{~kg} \mathrm{SP}-36$, and $100 \mathrm{~kg} \mathrm{KCl} \mathrm{ha}^{-1}$ season $^{-1}$, while the common farmer practices rate was 100 $\mathrm{kg}$ urea and $50 \mathrm{~kg} \mathrm{SP}-36 \mathrm{ha}^{-1}$ season $^{-1}$. The urea and $\mathrm{KCl}$ were split three times namely $50 \%$ at planting time, $25 \%$ at 21 DAT (days after transplanting), and the last $25 \%$ was given at 35 DAT. Rice straw compost of about $3 \mathrm{Mg} \mathrm{ha}^{-1}$ was broadcasted a week before planting. Only in treatment 
Table 1. The detailed treatments of NPK fertilization, biofertilizer, and rice straw compost under this study.

\begin{tabular}{|c|c|c|c|c|c|c|}
\hline Code & Treatment & Urea & SP-36 & $\mathrm{KCl}$ & $\begin{array}{c}\text { Smart/ } \\
\text { Biofertilizer }\end{array}$ & $\begin{array}{c}\text { Straw } \\
\text { Compost }\end{array}$ \\
\hline & & & & \multicolumn{3}{|c|}{ 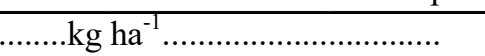 } \\
\hline T0 & Farmer Practices (as control) & 100 & 50 & - & - & - \\
\hline $\mathrm{T} 1$ & $\begin{array}{l}\text { NPK with recommendation rate }+ \text { Rice } \\
\text { Straw Compost }\end{array}$ & 250 & 100 & 100 & - & 3.000 \\
\hline $\mathrm{T} 2$ & $\begin{array}{l}\text { NPK with recommendation rate }+ \text { Smart }+ \\
\text { Rice Straw Compost }\end{array}$ & 250 & 100 & 100 & 10 & 2.000 \\
\hline $\mathrm{T} 3$ & $\begin{array}{l}3 / 4 \text { NPK with recommendation rate }+ \text { Smart } \\
+ \text { Rice Straw Compost }\end{array}$ & 187.50 & 75 & 75 & 10 & 2.000 \\
\hline $\mathrm{T} 4$ & $\begin{array}{l}\text { NPK with recommendation rate }+ \text { Smart }+ \\
\text { Compost, in which } \mathrm{N}, \mathrm{P} \text {, and } \mathrm{K} \text { were split } \\
\text { two times: } 50 \% \text { were given at planting } \\
\text { time and } 50 \% \text { was added at } 21 \text { days after } \\
\text { planting }\end{array}$ & 250 & 100 & 100 & 10 & 2.000 \\
\hline
\end{tabular}

$\mathrm{T} 4, \mathrm{~N}, \mathrm{P}$, and $\mathrm{K}$ fertilizers were applied two times: $50 \%$ at planting time, and $50 \%$ was given at 21 DAT. In the farmer practices, $\mathrm{N}$ was split two times, $50 \%$ at planting time and $50 \%$ at 21 DAT, while $\mathrm{P}$ was given one time at planting time. A week before broadcasting the compost, one $\mathrm{kg}$ of composite straw compost were taken and analyzed for its chemical contents. Biofertilizer namely Smart was applied as seed treatment with a rate of $10 \mathrm{~kg} \mathrm{ha}^{-}$ ${ }^{1}$ or $10 \mathrm{~kg}$ Smart for $25 \mathrm{~kg}$ seeds. The detailed treatments are presented in Table 1.

Ciherang rice variety was cultivated as a plant indicator. Transplanting was carried out at the beginning of March 2014 and harvest at the end of June 2014. Twenty-one-day-old seedlings were transplanted at about a $25 \mathrm{~cm} \times 25 \mathrm{~cm}$ cropping distance with about three seedlings per hill.

\section{Biomass and Rice Yields Quantification}

Rice biomass production including grains, straw, and residues were measured at harvest. When water content in rice grains was $16 \%$, the rice plants were harvested, and for measurement, the constant weight of rice grains yield the water content of $14 \%$ was used. Sampling units $(1 \mathrm{~m} \times 1 \mathrm{~m}$ plot $)$, were randomly selected at every plot. Rice plants were manually cut about 15 to $20 \mathrm{~cm}$ above the ground surface. The samples were manually separated into rice grains, rice straw, and rice residues. Rice residues included the roots and the part of the stem (stubble) left after cutting. Fresh weights of rice grain, rice straw, and rice residues were immediately weighed at harvest at each sampling unit. In inputoutput analysis, rice residue was not considered as an input, as it always remains in the field.
The inputs of nitrogen, phosphorous, and potassium were the sum of $\mathrm{N}, \mathrm{P}$, and $\mathrm{K}$ coming from mineral fertilizers (IN-1), rice straw compost (IN2), irrigation (IN-3), and precipitation (IN-4). Outputs were the sum of nitrogen, phosphorous, and potassium removed by rice grains (OUT-1) and rice straw (OUT-2). To quantify nitrogen, phosphorous, and potassium gains, data included concentrations of $\mathrm{N}, \mathrm{P}$ and $\mathrm{K}$ in urea, SP-36 and $\mathrm{KCl}$, rate of urea, SP-36 and $\mathrm{KCl}$, amount of $\mathrm{N}, \mathrm{P}$ and $\mathrm{K}$ in compost, irrigation water supply, $\mathrm{N}, \mathrm{P}$ and $\mathrm{K}$ concentrations in irrigation waters and rainfall were collected. The output parameters were rice grains yield, rice straw production, $\mathrm{N}, \mathrm{P}$, and $\mathrm{K}$ concentrations in rice grains and rice straw.

IN-1 and IN-2 were calculated based on the amount of mineral and organic fertilizers added multiplied by the concentration of $\mathrm{N}, \mathrm{P}$, and $\mathrm{K}$ in urea, SP-36, and $\mathrm{KCl}$ and compost, respectively. IN-3 was estimated according to water input and nutrients content in irrigation water. Water input was the difference between incoming water and outgoing water. Incoming water was calculated through water discharge multiplied by the time the inlet is open and close inlet and outlet during the rice life cycle, mainly from land soaking to the repining stage. As the N, P, and $\mathrm{K}$ concentrations from the outlet were not measured, thus the contribution of nitrogen, phosphorous, and potassium from irrigation water was predicted based on water input multiplied by the N, P, and $\mathrm{K}$ contents in incoming water, respectively. In this experiment, the pounding water layer was maintained at about three $\mathrm{cm}$. The water discharge was measured using the Floating method (WMO 1994). IN-4 was estimated by mul- 
tiplying rainfall volume with nitrogen, phosphorous, and potassium concentrations in the rainwater. On a hectare basis, it was counted as follows (Sukristiyonubowo 2007; WMO 1994.

$$
\mathrm{IN}-4=\frac{\mathrm{A} \times 10.000 \times 0.80 \times \mathrm{B} \times 1000}{1000 \times 10^{6}}
$$

Where:

- IN-4 is N, P or K input of rainfall water in $\mathrm{kg} \mathrm{N}$, $\mathrm{kg} \mathrm{P}$ and $\mathrm{K} \mathrm{ha}^{-1}$ season $^{-1}$

- A is rainfall in $\mathrm{mm}$

-10000 is conversion of ha to $\mathrm{m}^{2}$

- 0.80 is the correction factor, as not all rainwater goes into the soil

- $\mathrm{B}$ is $\mathrm{N}, \mathrm{P}$ and $\mathrm{K}$ concentrations in rainfall water in $\mathrm{mg} \mathrm{l}^{-1}$, respectively

-1000 is conversion from $\mathrm{m}^{3}$ to 1

- 1000 is conversion from $\mathrm{mm}$ to $\mathrm{m}$

$-10^{6}$ is conversion from $\mathrm{mg}$ to $\mathrm{kg}$

\section{Samples Analysis}

To monitor rainfall events, data from the rain gauge and climatology station of Malaka were considered. Rainwaters were sampled once during rice growth and development from a rain gauge in $600 \mathrm{ml}$ plastic bottles and were also analyzed according to the procedures of the Laboratory of the Soil Research Institute, Bogor (Soil Research Institute 2009).

Theoretically, the nitrogen loss can be through harvested products (rice grains and rice straw), leaching, and ammonia volatilization. Due to leaching and ammonia volatilization was not yet measured, thus the nitrogen loss was calculated only from the harvested product. Consequently, the total nitrogen output was a bit underestimated. Hence, nitrogen, phosphorous, and potassium losses were calculated through harvested products (rice grains and rice straw). As all rice grains were transported out of plots, OUT-1 was estimated based on rice grains yield multiplied with $\mathrm{N}, \mathrm{P}$, and $\mathrm{K}$ concentrations in the grains, respectively. OUT-2 was calculated according to the total rice straw production multiplied with $\mathrm{N}, \mathrm{P}$, and $\mathrm{K}$ concentrations in the straw, respectively. Rice straw was considered as output because all rice straw was taken out from the field for making compost and the compost is applied for the coming planting season.

For the laboratory analyses, rice plants from every plot with the best tiller number from the five teen samples of plant height (vegetative growth) were chosen. Plants were sampled at harvest and were collected from every plot, one hill per plot. After pulling out, the plant roots were washed with canal water. For the laboratory analyses, the samples were treated according to the procedures of the Analytical Laboratory of the Soil Research Institute, Bogor. Samples were washed with deionized water to avoid any contamination and oven-dried at $70^{\circ} \mathrm{C}$. The dried samples were ground and stored in plastic bottles. Nitrogen was determined by wet ashing using concentrated $\mathrm{H}_{2} \mathrm{SO}_{4}(97 \%)$ and selenium (Soil Research Institute 2009), P and $\mathrm{K}$ were measured after wet ashing using $\mathrm{HClO} 4$ and $\mathrm{HNO}_{3}$ (Soil Research Institute 2009).

\section{RESULTS AND DISCUSSION}

\section{Nitrogen, Phosphorous and Potassium Inputs}

Application of Urea, SP-36, and $\mathrm{KCl}(\mathrm{IN}-1)$, rice straw compost (IN-2), irrigation water (IN-3), and rainfall water (IN-4) are considered as the $\mathrm{N}, \mathrm{P}$, and $\mathrm{K}$ inputs and presented in Tables 2, 3, and 4. The IN1 (contribution of mineral fertilizer) varied from +45.00 for farmer practices to $+112.50 \mathrm{~kg} \mathrm{~N}$ ha- 1 season- 1 for recommendation rates and +8.00 for farmer practices and $+16.00 \mathrm{~kg} \mathrm{P} \mathrm{ha}^{-1}$ season $^{-1}$ for recommendation rates, while for potassium was about $+50.70 \mathrm{~kg} \mathrm{~K} \mathrm{ha}^{-1}$ season $^{-1}$ for recommendation rate (Table 2). Therefore, it can be concluded that the higher the dosage of urea, SP-36, and $\mathrm{KCl}$

Table 2. The contribution of inorganic fertilizer (IN-1) to N, P and K inputs.

\begin{tabular}{ccccccc}
\hline \multirow{2}{*}{ Treatment } & \multicolumn{3}{c}{$\begin{array}{c}\text { Rate of Fertilizer } \\
\left(\mathrm{kg} \mathrm{ha}^{-1} \text { season }^{-1}\right)\end{array}$} & \multicolumn{3}{c}{$\begin{array}{c}\text { Contribution of Mineral Fertilizer } \\
(\mathrm{IN}-1)\end{array}$} \\
\cline { 2 - 7 } & Urea & $\mathrm{SP}-36$ & $\mathrm{KCl}$ & $\begin{array}{c}\mathrm{IN}-1 \\
\left(\mathrm{~kg} \mathrm{~N} \mathrm{ha}^{-1} \text { season }^{-1}\right)\end{array}$ & $\begin{array}{c}\mathrm{IN}-1 \\
\left(\mathrm{kgP} \mathrm{ha}^{-1} \mathrm{season}^{-1}\right)\end{array}$ & $\begin{array}{c}\mathrm{IN}-1 \\
\left(\mathrm{~kg} \mathrm{~K} \mathrm{ha}^{-1} \mathrm{season}^{-1}\right)\end{array}$ \\
\hline $\mathrm{T} 0$ & 100 & 50 & - & 45 & 8.00 & - \\
$\mathrm{T} 1$ & 250 & 100 & 100 & 112.50 & 16.00 & 50.70 \\
$\mathrm{~T} 2$ & 250 & 100 & 100 & 112.50 & 16.00 & 50.70 \\
$\mathrm{~T} 3$ & 187.50 & 100 & 100 & 82.50 & 16.00 & 50.70 \\
$\mathrm{~T} 4$ & 250 & 100 & 100 & 112.50 & 16.00 & 50.70 \\
\hline
\end{tabular}


Table 3. The contribution of organic fertilizer (IN-2) to N, P and K inputs.

\begin{tabular}{ccccc}
\hline \multirow{2}{*}{ Treatment } & $\begin{array}{c}\text { Rate of Compost } \\
\left(\mathrm{kg} \mathrm{ha}^{-1} \text { season }^{-1}\right)\end{array}$ & $\begin{array}{c}\mathrm{IN}-2 \\
\left(\mathrm{~kg} \mathrm{~N} \mathrm{~h}^{-1} \mathrm{season}^{-1}\right)\end{array}$ & $\begin{array}{c}\text { Contribution of Compost (IN-2) } \\
\left(\mathrm{kg} \mathrm{P} \mathrm{ha}^{-1} \text { season }^{-1}\right)\end{array}$ & $\begin{array}{c}\mathrm{IN}-2 \\
\left(\mathrm{~kg} \mathrm{~K} \mathrm{ha}^{-1} \text { season }^{-1}\right)\end{array}$ \\
\hline T0 & - & - & - & - \\
T1 & 3000 & 30.60 & 4.80 & 83.70 \\
T2 & 2000 & 20.40 & 3.20 & 55.80 \\
T3 & 2000 & 20.40 & 3.20 & 55.80 \\
T4 & 2000 & 20.40 & 3.20 & 55.80 \\
\hline
\end{tabular}

fertilizers, the higher their contribution to the nitrogen, phosphorous, and potassium inputs (Table 2).

The IN-2, the contribution of rice straw compost was about +20.40 to $+30.60 \mathrm{~kg} \mathrm{~N} \mathrm{ha}^{-1}$, from the average of nitrogen contents in rice straw compost of $1.52 \%, 0.93 \%$, and $0.60 \% \mathrm{~N}$ and +3.20 to +4.80 $\mathrm{kg} \mathrm{P} \mathrm{ha}{ }^{-1}$ season $^{-1}$, from the mean of phosphorous content in rice straw compost of $0.09 \%, 0.11 \%$, and $0.27 \% \mathrm{P}$, while for $\mathrm{K}$ was about +55.80 to +83.70 $\mathrm{kg} \mathrm{K} \mathrm{ha-1}$ season $^{-1}$, from the average of $\mathrm{K}$ concentrations of $2.90 \%, 2.62 \%$ and $2.85 \% \mathrm{~K}$ (Table 3). Thus, besides the application rate of compost, the nutrient concentration in compost influenced the contribution. It can also be concluded that the application of two and three tons of rice straw compost ha- ${ }^{-1}$ season $^{-1}$ was higher than the application of $100 \mathrm{~kg} \mathrm{KCl} \mathrm{ha}^{-1}$ season $^{-1}$, the $\mathrm{KCl}$ recommendation rate.

While the contribution of nitrogen, phosphorous, and potassium inputs from irrigation water (IN-3) was about $+23.76 \mathrm{~kg} \mathrm{~N}$ equivalent to about
$55 \mathrm{~kg}$ urea and input from rainwater was about $+8.74 \mathrm{~kg} \mathrm{~N}$, equal to about $20 \mathrm{~kg}$ urea (Table 4) and $0.15 \mathrm{~kg} \mathrm{P} \mathrm{ha}^{-1}$ season $^{-1}$ equivalent to about 0.9 $\mathrm{kg} \mathrm{SP}-36 \mathrm{ha}^{-1}$ season $^{-1}$, meanwhile for potassium was about $+11.26 \mathrm{~kg} \mathrm{~K} \mathrm{ha}^{-1}$ season $^{-1}$ equivalent to about $22.52 \mathrm{~kg} \mathrm{KCl} \mathrm{ha}^{-1}$ season $^{-1}$ (Table 5), which was considered high, almost one-fourth of potassium fertilizer recommended rate.

The input from rainwater was about +0.38 $\mathrm{kg}$ P, equal to $2.40 \mathrm{~kg} \mathrm{SP}-36$, and for potassium was about $+0.77 \mathrm{~kg} \mathrm{~K}$ equal to $3.00 \mathrm{~kg} \mathrm{KCl} \mathrm{ha}^{-1}$ season $^{-1}$ (Table 6), which were considered insignificant. Similar results were found in the terraced paddy field system in the Semarang District of about $+20.6 \mathrm{~kg} \mathrm{~N},+2.6 \mathrm{~kg} \mathrm{P}$, and +6.1 $\mathrm{kg} \mathrm{K} \mathrm{ha}^{-1}$ season $^{-1}$ (Sukristiyonubowo 2007).

\section{Nitrogen, Phosphorous and Potassium Losses}

The losses of nitrogen, phosphorous, and potassium were estimated from rice grains (OUT1) and rice straw (OUT-2) taken out from the plots.

Table 4. The contribution of irrigation (IN-3) and rain water (IN-4) to nitrogen input( $\left.\mathrm{kg} \mathrm{N} \mathrm{ha}^{-1} \mathrm{season}^{-1}\right)$.

\begin{tabular}{cccccccc}
\hline \multirow{2}{*}{ Treatments } & \multicolumn{3}{c}{ water input, $\mathrm{NH}_{4}^{+}$and $\mathrm{NO}_{3}^{-}$concentration } & \multicolumn{3}{c}{ Rain Water } \\
\cline { 2 - 8 } & $\begin{array}{c}\text { Water } \\
\text { input }(\mathrm{L})\end{array}$ & $\begin{array}{c}\mathrm{NH}_{4}^{+} \\
\left(\mathrm{mg} \mathrm{l}^{-1}\right)\end{array}$ & $\begin{array}{c}\mathrm{NO}_{3}^{-} \\
\left(\mathrm{mg} \mathrm{l}^{-1}\right)\end{array}$ & $\begin{array}{c}\mathrm{IN}^{-3} \\
\left(\mathrm{~kg} \mathrm{~N} \mathrm{ha}^{-1}\right)\end{array}$ & $\begin{array}{c}\text { Rainfall } \\
\left(\mathrm{mm} \mathrm{yr}^{-1}\right)\end{array}$ & $\begin{array}{c}\mathrm{NH}_{4}^{+} \\
\left(\mathrm{mg} \mathrm{l}^{-1}\right)\end{array}$ & $\begin{array}{c}\mathrm{IN}^{-4} \\
\left(\mathrm{~kg} \mathrm{~N} \mathrm{ha}^{-1}\right)\end{array}$ \\
\hline T0-T4 & $15 \times 10^{6}$ & 0.77 & 0.92 & 23.76 & 1200 & 0.91 & 8.74 \\
\hline
\end{tabular}

Note: T0: Farmer Practices (as control)

T1: NPK at recommnendatin rate + Rice straw Compost

T2: NPK at recommendation rate + Smart + Rice straw Compost

T3:3/4 NPK with recommendation rate + Smart + Rice straw Compost

T4: NPK at recommendation rate + Smart + Rice straw Compost (N, P and K were split $2 \times)$

Table 5. The contribution of irrigation water (IN-3) to phosphorous and potassium inputs.

\begin{tabular}{cccccc}
\hline \multirow{2}{*}{ Treatment } & \multicolumn{2}{c}{ Water input, P and K concentrations } & \multicolumn{2}{c}{ Contribution to input } \\
\cline { 2 - 6 } & $\begin{array}{c}\text { Water input } \\
(\mathrm{L})\end{array}$ & $\begin{array}{c}\mathrm{PO}_{4}^{3-} \text { Concen. } \\
\left(\mathrm{mg} \mathrm{l}^{-1}\right)\end{array}$ & $\begin{array}{c}\text { K Concen. } \\
\left(\mathrm{mg} \mathrm{l}^{-1}\right)\end{array}$ & $\begin{array}{c}\mathrm{IN}-3 \\
\left(\mathrm{~kg} \mathrm{P} \mathrm{ha}^{-1} \text { season }^{-1}\right)\end{array}$ & $\begin{array}{c}\text { IN-3 } \\
\left(\mathrm{kg} \mathrm{K} \mathrm{ha}^{-1} \text { season }^{-1}\right)\end{array}$ \\
\hline T0-T4 & $15 \times 10^{6}$ & 0.03 & 0.76 & 0.15 & 11.26 \\
\hline
\end{tabular}


Table 6. The contribution of rain water (IN-4) to phosphorous and potassium inputs.

\begin{tabular}{cccccc}
\hline \multirow{2}{*}{ Treatment } & \multicolumn{2}{c}{ Rainfall, $\mathrm{P}$ and K concentrations } & \multicolumn{2}{c}{ Contribution to input } \\
\cline { 2 - 6 } & $\begin{array}{c}\text { Rainfall } \\
(\mathrm{mm})\end{array}$ & $\begin{array}{c}\mathrm{P} \text { Concen. } \\
\left(\mathrm{mg} \mathrm{PO}_{4} \mathrm{l}^{-1}\right)\end{array}$ & $\begin{array}{c}\mathrm{K} \mathrm{Concen}^{-1} \\
\left(\mathrm{mg} \mathrm{K} \mathrm{l}^{-1}\right)\end{array}$ & $\begin{array}{c}\mathrm{IN}-4 \\
\left(\mathrm{~kg} \mathrm{P} \mathrm{ha}^{-1} \text { season }^{-1}\right)\end{array}$ & $\begin{array}{c}\mathrm{IN}-4 \\
\left(\mathrm{~kg} \mathrm{~K} \mathrm{ha}^{-1} \mathrm{season}^{-1}\right)\end{array}$ \\
\hline T0-T4 & 1200 & 0.04 & 0.08 & 0.38 & 0.77 \\
\hline
\end{tabular}

The N, P and $\mathrm{K}$ loss are presented in Tables 7, 8, and 9 . Nitrogen removed by rice grains varied from -30.27 to $-53.87 \mathrm{~kg} \mathrm{~N}^{-1} \mathrm{~h}^{-1}$ season $^{-1}$ depending on rice grains yield. Nitrogen removed by rice straw was about -19.84 to $-35.73 \mathrm{~kg} \mathrm{~N} \mathrm{ha}^{-1}$ season $^{-1}$. The highest $\mathrm{N}$ removed by rice grains was shown by $\mathrm{T} 1$ and by rice straw was by $\mathrm{T} 3$. However, the total $\mathrm{N}$ taken away by harvest product of about $\mathrm{kg}$ $-85.72 \mathrm{~N} \mathrm{ha}^{-1}$ season $^{-1}$ was shown by $\mathrm{T} 1$ because of the highest rice grains yield and rice straw of this treatment (Table 7). Therefore, it can be said that increasing rice harvest product remove more nitrogen.

$\mathrm{P}$ taken away by rice grains ranged between 8.69 and $-16.90 \mathrm{~kg} \mathrm{P} \mathrm{ha}^{-1}$ season $^{-1}$ depending on the rice grains production. While $\mathrm{P}$ removed by rice straw varied from -2.48 to $-3.57 \mathrm{~kg} \mathrm{P} \mathrm{ha}^{-1}$ season $^{-1}$. The highest $\mathrm{P}$ removed by rice grains was shown by $\mathrm{T} 1$ and by rice straw was by $\mathrm{T} 3$. However, the total $\mathrm{P}$ removed by harvest product of about -20.47 $\mathrm{kg} \mathrm{P} \mathrm{ha}{ }^{-1}$ season $^{-1}$ was shown by T3 because of the highest rice grains yield and rice straw of this treatment (Table 8). Therefore, it can be said that increasing rice harvest product also remove more phosphorous.

Potassium removed by rice grain ranged between -15.46 and $-34.02 \mathrm{~kg} \mathrm{~K} \mathrm{ha}^{-1}$ season $^{-1}$ depending on the rice grains production. $\mathrm{K}$ removed by rice straw varied from -45.63 to $-81.20 \mathrm{~kg} \mathrm{~K} \mathrm{ha}^{-1}$ season $^{-1}$ (Tabel 9). The highest $\mathrm{K}$ removed by rice grains was shown by $\mathrm{T} 1$ as well as rice straw. Thus, total $\mathrm{K}$ removed by harvest product of about -115.22 $\mathrm{kg} \mathrm{K} \mathrm{ha}{ }^{-1}$ season $^{-1}$ was shown by $\mathrm{T} 1$ because of the highest rice yield and rice straw of this treatment. Therefore, it can also be said that increasing rice harvest product remove more potassium.

Table 7. Rice biomass production including rice grains and rice straw of Ciherang variety and total nitrogen loss from rice grains (OUT-1) and rice straw (OUT-2).

\begin{tabular}{|c|c|c|c|c|c|c|c|}
\hline \multirow[t]{2}{*}{ Treatments } & \multicolumn{2}{|c|}{$\begin{array}{l}\text { Biomass Production } \\
\left(\mathrm{Mg} \mathrm{ha}^{-1} \text { season- }{ }^{-1}\right)\end{array}$} & \multicolumn{2}{|c|}{$\begin{array}{c}\text { N concentration } \\
(\%)\end{array}$} & \multicolumn{2}{|c|}{$\begin{array}{c}\mathrm{N} \text { loss } \\
\left(\mathrm{kg} \mathrm{N} \mathrm{ha}^{-1} \text { season }^{-1}\right)\end{array}$} & \multirow[t]{2}{*}{ Total N loss } \\
\hline & $\begin{array}{l}\text { Rice } \\
\text { Grains }\end{array}$ & $\begin{array}{l}\text { Rice } \\
\text { Straw }\end{array}$ & $\begin{array}{l}\text { Rice } \\
\text { Grains }\end{array}$ & $\begin{array}{l}\text { Rice } \\
\text { Straw }\end{array}$ & OUT-1 & OUT-2 & \\
\hline T0 & $3.22 \mathrm{a}$ & $2.48 \mathrm{a}$ & 0.94 & 0.80 & 30.27 & 19.84 & 50.11 \\
\hline $\mathrm{T} 1$ & $5.67 \mathrm{~b}$ & $3.50 \mathrm{ab}$ & 0.95 & 0.91 & 53,87 & 31.85 & 85.72 \\
\hline $\mathrm{T} 2$ & $5.27 \mathrm{~b}$ & $3.37 \mathrm{ab}$ & 1.01 & 0.88 & 53.23 & 29.66 & 82.89 \\
\hline $\mathrm{T} 3$ & $4.97 \mathrm{~b}$ & $3.97 \mathrm{~b}$ & 1.00 & 0.90 & 49.70 & 35.73 & 85.43 \\
\hline $\mathrm{T} 4$ & $4.88 \mathrm{~b}$ & $2.97 \mathrm{a}$ & 0.97 & 0.87 & 47.34 & 25.84 & 73.18 \\
\hline
\end{tabular}

Table 8. Rice biomass production including rice grain and rice straw of Ciherang variety and total P loss from rice grains (OUT-1) and rice straw (OUT-2).

\begin{tabular}{cccccccc}
\hline \multirow{2}{*}{ Treatments } & \multicolumn{2}{c}{$\left.\begin{array}{c}\text { Biomass Production } \\
\left(\mathrm{Mg} \mathrm{ha}^{-1} \text { season- }\right.\end{array}{ }^{-1}\right)$} & \multicolumn{2}{c}{$\begin{array}{c}\text { P concentration } \\
(\%)\end{array}$} & \multicolumn{2}{c}{$\begin{array}{c}\text { P loss } \\
\left(\mathrm{kg} \mathrm{P} \mathrm{ha}^{-1} \text { season }^{-1}\right)\end{array}$} & \multirow{2}{*}{ Total P loss } \\
\cline { 2 - 7 } & $\begin{array}{c}\text { Rice } \\
\text { Grains }\end{array}$ & $\begin{array}{c}\text { Rice } \\
\text { Straw }\end{array}$ & $\begin{array}{c}\text { Rice } \\
\text { Grains }\end{array}$ & $\begin{array}{c}\text { Rice } \\
\text { Straw }\end{array}$ & OUT-1 & OUT-2 & \\
\hline T0 & $3.22 \mathrm{a}$ & $2.48 \mathrm{a}$ & 0.27 & 0.10 & 8.69 & 2.48 & 11.17 \\
T1 & $5.67 \mathrm{~b}$ & $3.50 \mathrm{ab}$ & 0.29 & 0.09 & 16.44 & 3.15 & 19.59 \\
T2 & $5.27 \mathrm{~b}$ & $3.37 \mathrm{ab}$ & 0.29 & 0.08 & 15.28 & 2.70 & 17.98 \\
T3 & $4.97 \mathrm{~b}$ & $3.97 \mathrm{~b}$ & 0.34 & 0.09 & 16.90 & 3.57 & 20.47 \\
T4 & $4.88 \mathrm{~b}$ & $2.97 \mathrm{a}$ & 0.31 & 0.09 & 15.13 & 2.67 & 17.80 \\
\hline
\end{tabular}


Table 9. Rice biomass production including rice grain and rice straw of Ciherang variety and total $\mathrm{K}$ loss from rice grain (OUT-1) and rice straw (OUT-2).

\begin{tabular}{cccccccc}
\hline \multirow{2}{*}{ Treatments } & \multicolumn{2}{c}{$\begin{array}{c}\text { Biomass Production } \\
\left(\mathrm{Mg} \mathrm{ha}^{-1} \text { season }^{-1}\right)\end{array}$} & \multicolumn{2}{c}{$\begin{array}{c}\text { K concentration } \\
(\%)\end{array}$} & \multicolumn{2}{c}{$\begin{array}{c}\text { K loss } \\
\left(\mathrm{kg} \mathrm{K} \mathrm{ha}^{-1} \text { season }^{-1}\right)\end{array}$} & \multirow{2}{*}{ Total K loss } \\
\cline { 2 - 7 } & $\begin{array}{c}\text { Rice } \\
\text { Grains }\end{array}$ & $\begin{array}{c}\text { Rice } \\
\text { Straw }\end{array}$ & $\begin{array}{c}\text { Rice } \\
\text { Grains }\end{array}$ & $\begin{array}{c}\text { Rice } \\
\text { Straw }\end{array}$ & OUT-1 & OUT-2 & \\
\hline T0 & $3.22 \mathrm{a}$ & $2.48 \mathrm{a}$ & 0.48 & 1.84 & 15.46 & 45.63 & 61.09 \\
T1 & $5.67 \mathrm{~b}$ & $3.50 \mathrm{ab}$ & 0.60 & 2.32 & 34.02 & 81.20 & 115.22 \\
T2 & $5.27 \mathrm{~b}$ & $3.37 \mathrm{ab}$ & 0.55 & 2.05 & 28.98 & 69.09 & 98.07 \\
T3 & $4.97 \mathrm{~b}$ & $3.97 \mathrm{~b}$ & 0.54 & 1.73 & 26.84 & 68.68 & 95.52 \\
T4 & $4.88 \mathrm{~b}$ & $2.97 \mathrm{a}$ & 0.60 & 1.97 & 29.28 & 58.50 & 87.78 \\
\hline
\end{tabular}

Table 10. Output-input analysis of nitrogen at study on nutrient balances at plot scale of newly developed lowland rice field at Kleseleon site, Malaka District, Nusa Tenggara Timur Province ( $\mathrm{kg} \mathrm{N} \mathrm{ha}^{-1}$ season $\left.^{-1}\right)$.

\begin{tabular}{|c|c|c|c|c|c|c|c|c|c|}
\hline \multirow{2}{*}{ Treatments } & \multicolumn{5}{|c|}{ N INPUT ( $\mathrm{kg} \mathrm{N} \mathrm{ha}^{-1}$ season $^{-1}$ ) } & \multicolumn{3}{|c|}{$\begin{array}{c}\text { N OUTPUT } \\
\left(\mathrm{kg} \mathrm{N} \mathrm{ha}^{-1} \text { season }^{-1}\right)\end{array}$} & \multirow{2}{*}{ N Balance } \\
\hline & $\mathrm{IN}-1$ & $\mathrm{IN}-2$ & IN-3 & IN-4 & $\begin{array}{l}\text { Total N } \\
\text { INPUT }\end{array}$ & OUT-1 & OUT-2 & $\begin{array}{c}\text { Total N } \\
\text { OUTPUT }\end{array}$ & \\
\hline \multirow[t]{2}{*}{ To } & 45.00 & - & 23.76 & 8.74 & 77.50 & -30.27 & -19.84 & -50.11 & +27.39 \\
\hline & $58 \%$ & - & $30 \%$ & $12 \%$ & $100 \%$ & $60 \%$ & $40 \%$ & $100 \%$ & \\
\hline \multirow[t]{2}{*}{$\mathrm{T} 1$} & 112.50 & 30.60 & 23.76 & 8.74 & 175.60 & -53.87 & -31.87 & -85.72 & +89.88 \\
\hline & $64 \%$ & $17 \%$ & $13 \%$ & $6 \%$ & $100 \%$ & $63 \%$ & $37 \%$ & $100 \%$ & \\
\hline \multirow[t]{2}{*}{$\mathrm{T} 2$} & 112.50 & 20.40 & 23.76 & 8.74 & 165.40 & -53.23 & -29.66 & -82.89 & +82.66 \\
\hline & $68 \%$ & $12 \%$ & $14 \%$ & $6 \%$ & $100 \%$ & $64 \%$ & $36 \%$ & $100 \%$ & \\
\hline \multirow[t]{2}{*}{$\mathrm{T} 3$} & 82.50 & 20.40 & 23.76 & 8.74 & 135.40 & -49.70 & -35.79 & -85.49 & +49.91 \\
\hline & $61 \%$ & $15 \%$ & $17 \%$ & $7 \%$ & $100 \%$ & $59 \%$ & $41 \%$ & $100 \%$ & \\
\hline \multirow[t]{2}{*}{$\mathrm{T} 4$} & 112.50 & 20.40 & 23.76 & 8.74 & 165.40 & -47.34 & -25.84 & -83.18 & +82.22 \\
\hline & $68 \%$ & $12 \%$ & $14 \%$ & $6 \%$ & $100 \%$ & $57 \%$ & $43 \%$ & $100 \%$ & \\
\hline
\end{tabular}

\section{Output-Input Analysis}

The N, P and $\mathrm{K}$ balances of newly developed lowland rice are presented in Tables 10, 11, and 12. In general, the results indicated that inorganic fertilizer (IN-1) contributes considerably to total N, P, and $\mathrm{K}$ input in all treatments. The amounts varied from +45.00 to $+112.50 \mathrm{~kg} \mathrm{~N}^{-1}$ season $^{-1}$ depending on the treatment. The contribution to $\mathrm{P}$ was about +8.00 to $+16.00 \mathrm{~kg} P$ depending on treatment and about $+50.70 \mathrm{~kg} \mathrm{~K}^{-1}$ season $^{-1}$, respectively. In the T1 to T4 treatments, IN-1 contributed about $75 \%$ to $84 \%$ of the total input of $\mathrm{P}$ (Table 11) and from 35 to $43 \%$ of total $\mathrm{K}$ inputs (Table 12 ).

Rice straw compost (IN-2) was also an essential nutrient source, contributing about $12 \%$ to $17 \%$ of total N (Table 10 ); $16 \%$ to $22 \%$ of total $\mathrm{P}$ (Table 11), and from 47 to $56 \%$ of total $\mathrm{K}$ input (Table 12) depending on the treatment. The IN-2 is more important when less or no inorganic fertilizers are applied and more organic fertilizer is added.
Nutrient supplied by compost was equivalent to about 45- $68 \mathrm{~kg}$ of urea; $20-25 \mathrm{~kg}$ of SP-36 and about 110 - $130 \mathrm{~kg} \mathrm{kcal}$. There will be more nutrients when the rate of compost application increased.

In general, the assessment of nitrogen input and output showed a surplus or positive balance for all treatments (Table 10). The surplus ranged between +27.39 and $+89.88 \mathrm{~kg} \mathrm{~N} \mathrm{ha}^{-1}$ season $^{-1}$, depending on the treatment. The nitrogen balances in the $\mathrm{T} 1$, $\mathrm{T} 2$, and $\mathrm{T} 4$ were more surplus than in the other treatments. This may be explained by the increase in nitrogen fertilizer application rate. It should also be noted that the $\mathrm{N}$ output will even be higher when $\mathrm{NH}_{3}$ volatilization and leaching are taken into account.

Like nitrogen evaluation, assessment of $\mathrm{P}$ input and output shows a positive balance for all treatments (Table 11). The surplus of $P$ ranged between +1.74 and $+1.93 \mathrm{~kg} \mathrm{P} \mathrm{ha}^{-1}$ season $^{-1}$. The $\mathrm{P}$ balances in the $\mathrm{T} 4$ was the best surplus compared to the other treatments. Although the amounts of potassium com- 
Table 11. Output-input analysis of phosphorus, study on nutrient balances at plot scale of newly developed lowland rice field at Kleseleon site, Malaka District, Nusa Tenggara Timur Province (kg P ha $^{-1}$ season $\left.^{-1}\right)$.

\begin{tabular}{cccccccccc}
\hline & \multicolumn{3}{c}{ P INPUT $\left(\mathrm{kg} \mathrm{P} \mathrm{ha}^{-1}\right.$ season $\left.^{-1}\right)$} & \multicolumn{5}{c}{$\begin{array}{c}\text { P OUTPUT } \\
\text { Treatments }\end{array}$} \\
\cline { 2 - 8 } & IN-1 & IN-2 & IN-3 & IN-4 & $\begin{array}{c}\text { Total P } \\
\text { INPUT }\end{array}$ & OUT-1 & OUT-2 & Total P \\
OUTPUT & P Balance \\
\hline To & +8.00 & - & +0.15 & +0.38 & +8.53 & -8.69 & -2.48 & -11.17 & -2.64 \\
& $94 \%$ & $0 \%$ & $2 \%$ & $4 \%$ & $100 \%$ & $78 \%$ & $22 \%$ & $100 \%$ & \\
T1 & +16.00 & +4.80 & +0.15 & +0.38 & +21.33 & -16.44 & -3.15 & -19.59 & +1.74 \\
& $75 \%$ & $22 \%$ & $1 \%$ & $2 \%$ & $100 \%$ & $84 \%$ & $16 \%$ & $100 \%$ & \\
T2 & +16.00 & +3.20 & +0.15 & +0.38 & +19.73 & -15.28 & -2.70 & -17.98 & +1.75 \\
& $81 \%$ & $16 \%$ & $1 \%$ & $2 \%$ & $100 \%$ & $85 \%$ & $15 \%$ & $100 \%$ & \\
T3 & +16.00 & +3.20 & +0.15 & +0.38 & +19.73 & -16.90 & -3.57 & -20.47 & -0.97 \\
& $81 \%$ & $16 \%$ & $1 \%$ & $2 \%$ & $100 \%$ & $82 \%$ & $18 \%$ & $100 \%$ & \\
T4 & +16.00 & +3.20 & +0.15 & +0.38 & +19.73 & -15.13 & -2.67 & -17.80 & +1.93 \\
& $81 \%$ & $16 \%$ & $1 \%$ & $2 \%$ & $100 \%$ & $85 \%$ & $15 \%$ & $100 \%$ & \\
\hline
\end{tabular}

ing from irrigation water (IN-3) were smaller compared to the amounts of nutrients originating from inorganic fertilizers (IN-1) and organic fertilizer (IN2), the contributions of IN-3 to K inputs were still important, covering between $8 \%$ and $93 \%$ of the total $\mathrm{K}$ inputs (Table 12).

Similar to the $\mathrm{P}$ balance, $\mathrm{K}$ input and Output analysis also indicated positive balances for all treatments (Table 12). The surplus ranged from +20.46 to $+31.72 \mathrm{~kg} \mathrm{~K} \mathrm{ha}^{-1}$ season $^{-1}$, depending on the treatment. For T1 and T4, the $\mathrm{K}$ balances were also more positive than the others. These were due to $\mathrm{K}$ input from compost were higher than other treatments. To replace $\mathrm{K}$ taken out by rice harvest products, therefore, $\mathrm{K}$ fertilizer application rate should be sustained to $100 \mathrm{~kg} \mathrm{KCl} \mathrm{ha}^{-1}$ season $^{-1}$ when the rate of compost was not increased. However, when the compost is increased to more than 3 tons ha $^{-1}$ season $^{-1}$ as the compost from rice straw is rich in $\mathrm{K}$, then application mineral fertilizer rate can be reduced. Regarding the farmers' condition, the last option was more feasible since the rice straw is available in the fields.

The positive N, $P$, and $K$ balances in all treatments also demonstrated that the application rates of organic and inorganic fertilizers were more than enough to substitute $\mathrm{N}, \mathrm{P}$, and $\mathrm{K}$ removed by rice grains and straw. But when $\mathrm{P}$ and $\mathrm{K}$ fertilizers application rates were less than $100 \mathrm{~kg} \mathrm{ha}^{-1}$ season $^{-1}$ or no application $\mathrm{P}$ dan $\mathrm{K}$ fertilizers were added, the deficit or negative $\mathrm{P}$ and $\mathrm{K}$ balances occurred. Therefore, it can be said that the $\mathrm{P}$ and $\mathrm{K}$ fertilizer

Table 12. Input-output analysis for potassium, study on nutrient balances at plot scale of newly developed lowland ricefield at Kleseleon site, Malaka District, Nusa Tenggara Timur Province (kg K ha-1 season $^{-1}$ ).

\begin{tabular}{|c|c|c|c|c|c|c|c|c|c|}
\hline \multirow{2}{*}{ Treatments } & \multicolumn{5}{|c|}{ K INPUT (kg K ha ${ }^{-1}$ season $^{-1}$ ) } & \multicolumn{3}{|c|}{$\begin{array}{c}\text { K OUTPUT } \\
\left(\text { Kg K ha }^{-1} \text { season }^{-1}\right) \\
\end{array}$} & \multirow{2}{*}{ K Balance } \\
\hline & IN-1 & $\mathrm{IN}-2$ & IN-3 & IN-4 & $\begin{array}{c}\text { Total K } \\
\text { Input }\end{array}$ & OUT-1 & OUT-2 & $\begin{array}{l}\text { Total K } \\
\text { Output }\end{array}$ & \\
\hline \multirow{2}{*}{ T0 } & - & - & +11.26 & +0.77 & +12.03 & -15.46 & -45.63 & -61.09 & \multirow{2}{*}{-49.06} \\
\hline & & & $93 \%$ & $7 \%$ & $100 \%$ & $25 \%$ & $75 \%$ & $100 \%$ & \\
\hline \multirow{2}{*}{$\mathrm{T} 1$} & +50.70 & +83.70 & +11.26 & +0.77 & +146.43 & -34.02 & -81.20 & -115.22 & \multirow{2}{*}{+31.21} \\
\hline & $35 \%$ & $56 \%$ & $8 \%$ & $1 \%$ & $100 \%$ & $30 \%$ & $70 \%$ & $100 \%$ & \\
\hline \multirow{2}{*}{$\mathrm{T} 2$} & +50.70 & +55.80 & +11.26 & +0.77 & +118.53 & -28.98 & -69.09 & -98.07 & \multirow{2}{*}{+20.46} \\
\hline & $43 \%$ & $47 \%$ & $9 \%$ & $1 \%$ & $100 \%$ & $29 \%$ & $71 \%$ & $100 \%$ & \\
\hline \multirow{2}{*}{ T3 } & +50.70 & +55.80 & +11.26 & +0.77 & +118.53 & -26.84 & -68.68 & -95.92 & \multirow{2}{*}{+22.61} \\
\hline & $43 \%$ & $47 \%$ & $9 \%$ & $1 \%$ & $100 \%$ & $27 \%$ & $73 \%$ & $100 \%$ & \\
\hline \multirow{2}{*}{$\mathrm{T} 4$} & +50.70 & +55.80 & +11.26 & +0.77 & +119.50 & -29.28 & -58.50 & -87.78 & \multirow{2}{*}{+31.72} \\
\hline & $43 \%$ & $47 \%$ & $9 \%$ & $1 \%$ & $100 \%$ & $33 \%$ & $67 \%$ & $100 \%$ & \\
\hline
\end{tabular}


application rate should be maintained as well as the application of compost as $\mathrm{P}$ can be longer kept in the soil without damage the environment and will improve soil function. As rice straw was a lot in the rice fields and can easily be composted, to replace $\mathrm{N}$ and $\mathrm{K}$ removed by rice harvest product and keep the higher rice grains yield, the organic fertilizer can be increased to more than $3000 \mathrm{~kg}$ compost ha ${ }^{-1}$ season $^{-1}$.

\section{CONCLUSIONS}

Assessment of N, P, and $\mathrm{K}$ inputs and outputs of newly developed lowland rice in Malaka District indicated that there were surplus $\mathrm{N}, \mathrm{P}$, and $\mathrm{K}$ balances. The surplus of nitrogen varied from +27.39 to $+89.88 \mathrm{~kg} \mathrm{~N}$ and $\mathrm{P}$ and $\mathrm{K}$ were from +1.74 to $+1.93 \mathrm{~kg} \mathrm{P}$ and +20.48 to $+31.72 \mathrm{~kg} \mathrm{~K} \mathrm{ha}^{-1}$ season $^{-1}$, respectively. To keep high rice production, the $\mathrm{N}, \mathrm{P}$, and $\mathrm{K}$ fertilizer rates were $100 \mathrm{~kg}$ urea, $100 \mathrm{~kg}$ SP-36, and $100 \mathrm{~kg} \mathrm{KCl} \mathrm{ha}^{-1}$ season $^{-1}$ plus $3000 \mathrm{~kg}$ straw compost ha- ${ }^{-1}$ season $^{-1}$.

\section{ACKOWLEDLEGMENT}

We thank the Minister of Agriculture of the Republic of Indonesia for funding this experiment. We thank also Mr. Didik S Hastono and Mr. Rahmat Hidayat for spending their time in the field.

\section{REFERENCES}

Bationo A, F Lompo and S Koala. 1998. Research on nutrient flows and balances in West Africa: Stateof-the-art. Agr Water Manage 71: 19-35.

Harris FMA. 1998. Farm-level assessment of the nutrient balance in northern Nigeria. Agr Ecosys Environ 71: 201-214.

Drechsel P, K Dagmar and FP de Vries. 2001. Soil nutrient depletion and population growth in Sub-Saharan Africa: A Malthusian Nexus? Popul Environ 22: 411-423.

Hashim GM, KJ Caughlan and JK Syers. 1998. On-site nutrient depletion: An effect and a cause of soil erosion. In: FWT Penning de Vries, F Agus and J Kerr (Eds), Soil Erosion at Multiple Scale. Principles and Methods for Assessing Causes and Impacts. CABI Publishing in Association with IBSRAM, pp. 207-222.

Lefroy RDB and J Konboon. 1999. Studying nutrient flows to assess sustainability and identify areas of nutrient depletion and imbalance: an example for rainfed rice systems in Northeast Thailand. In: Ladha (eds), Rainfed Lowland Rice: Advances in Nutrient Management Research. IRRI, pp. 77-93

Miller RJ and RB Smith. 1976. Nitrogen balance in the Southern San Joaquin Valley. J Environ Qual 5: 274-278.
Nkonya E, C Kaizzi and J Pender. 2005. Determinants of nutrient balances in a maize farming system in eastern Uganda. Agric Syst 85: 155-182.

Santoso D, IGP Wigena, Z Eusof and XH Chen. 1995. The ASIALAND management of sloping lands network: Nutrient balance study on sloping lands. In: International Workshop on Conservation Farming for Sloping Uplands in Southeast Asia: Challenges, Opportunities, and Prospects. IBSRAM-Thailand Proceedings. 14, pp. 93-108

Sheldrick WF, J Keith Syers and J Lingard. 2003. Soil nutrient audits for China to estimate nutrient balance and output/input relationships. Agric Ecosyst Environ 94: 341-354.

Syers JK. 1996. Nutrient budgets: uses and abuses. In Soil data for sustainable land uses: A training workshop for Asia. IBSRAM-Thailand Proceedings. 15, pp. 163-168

Smaling EMA, JJ Stoorvogel, PN Wiindmeijer. 1993. Calculating soil nutrient balances in Africa at different scales II. District scale. Fertil Res 35: 237-250.

Soil Research Institute. 2009. Penuntun analisa kimia tanah, tanaman, air dan pupuk (Procedure to measure soil chemical, plant, water and fertiliser). Soil Research Institute, Bogor. 234 p. (in Indonesian)

Stoorvogel JJ, EMA Smaaling, BH Janssen. 1993. Calculating soil nutrient balances in Africa at different scales. I. Supra-national scale. Fertil Res 35: 227-236.

Sukristiyonubowo. 2007. Nutrient balances in terraced paddy fields under traditional irrigation in Indonesia. PhD thesis. Faculty of Bioscience Engineering, Ghent University, Ghent, Belgium. 184p.

Sukristiyonubowo, G Du Laing, M G Verloo. 2010. Nutrient balances of wetland rice for the Semarang District. J Sustain Agr 34: 850-861.

Sukristiyonubowo, Etty Pratiwi, Kusumo Nugroho, Tagus Vadari, Heri Wibowo. 2014. Laporan akhir Penelitian dan Pengembangan Teknologi Pengelolaan lahan untuk meningkatkan produktivitas sawah bukaan baru. 38p.(in Indonesian).

Sukristiyonubowo, S Widodo and K Nugroho. 2017. Plot Scale Nitrogen Balance of Newly Developed Lowland Rice at Kleseleon Village Malaka District, Nusa Tenggara Timur 41, pp. 115-122.

Van den Bosch H, A. de Joger, J Vlaming. 1998a. Monitoring nutrient flows and economic performance in African farming systems (NUTMON) II. Tool Development. Agr Ecosys Environ 71: 49-62.

Van den Bosch H, JN Gitari, VN Ogoro, S Maobe, J Vlaming. 1998b. Monitoring nutrient flows and economic performance in African farming systems (NUTMON) III. Monitoring nutrient flows and balances in three districts in Kenya. Agr Ecosys Environ 71: 63-80

WMO [World Meteorological Organisation]. 1994. Guide to hydrological practices. Data acquisition and processing, analysis, forecasting and other applications. Fifth ed. WMO-No.168. 735p. 